\title{
SIMULASI REAKSI ESTERIFIKASI ASAM LEMAK BEBAS DAN GLISEROL UNTUK MENGHASILKAN MINYAK DIASILGLISEROL
}

\author{
Heri Hermansyah ${ }^{*}$, Tania Surya Utami, Rita Arbianti dan Fajar Achmadi \\ Departemen Teknik Kimia, Fakultas Teknik, Universitas Indonesia, \\ Kampus Baru UI Depok 16424, Telp. (021) 7863576 \\ ${ }^{*}$ Penulis korespondensi: heri@chemeng.ui.ac.id
}

\begin{abstract}
Abstrak
Minyak yang memiliki kandungan diasilgliserol yang tinggi merupakan minyak yang berguna dalam mencegah penyakit yang disebabkan oleh kadar lemak dalam darah serta dapat mengurangi resiko obesitas. Sintesis DAG pada skala industri telah dilakukan melalui esterifikasi asam lemak bebas dengan gliserol menggunakan biokatalis. Untuk lebih memahami perilaku reaksi sintesis DAG, dilakukan simulasi berdasarkan model yang mengacu pada mekanisme reaksi yang diusulkan. Model kemudian divalidasi menggunakan data eksperimen sebelum dilakukan simulasi. Pengaruh rasio konsentrasi awal reaktan terhadap yield maksimum DAG, konversi masing-masing reaktan, serta profil konsentrasi substrat sebagai fungsi waktu diamati, hasilnya menunjukkan rasio konsentrasi awal asam lemak dan gliserol sebesar 2:1 sebagai rasio konsentrasi awal reaktan untuk memperoleh hasil optimum.
\end{abstract}

Kata kunci: diasilgliserol, esterifikasi, simulasi

\begin{abstract}
Oil with high DAG content is useful for preventing disease which is related to fat concentration in blood and also can decrease risk of obesity. Synthesis of DAG on industrial scale is done by esterification of free fatty acid and glycerol using biocatalyst. For further understanding about behaviour of reaction for synthesis of DAG, simulation with model based on a proposed mechanism is done. Model then validated using experimental data before starting the simulation. Effect of initial substrate concentration ratio to maximum yield of DAG, each reactant conversion, and time course of the substrates is observed, as a result, initial concentration of substrates ratio as much as 2:1 shown as the best ratio to obtain optimum process condition.
\end{abstract}

Keywords: diacylglycerol, etherification, simulation

\section{PENDAHULUAN}

Minyak dikonsumsi setiap hari oleh hampir semua orang. Selain mengandung nutrisi esensial, minyak juga berperan dalam membentuk rasa dan aroma pada makanan. Untuk menghindari terjadinya penyakit yang berkaitan dengan peningkatan kadar lemak dalam darah, berbagai penelitian dilakukan untuk mendapatkan minyak goreng sehat. Studi yang dilakukan di Jepang melaporkan 1,3-diasilgliserol (1,3-DAG), yang terdapat pada minyak dan lemak alami dalam jumlah sedikit, mampu menurunkan peningkatan kadar lemak dalam darah setelah emulsi lemak ditelan (Tada et al., 2001). Dalam jangka panjang, minyak yang kaya akan 1,3-DAG mampu menurunkan kadar lemak tubuh (Maki et al., 2002) dan berat badan (Nagao et al., 2000) sehingga digunakan dalam diet untuk mencegah obesitas dan penyakit yang berkaitan dengan gaya hidup (Flickinger and Matsuo, 2003).

Untuk memproduksi minyak DAG dalam skala industri, diperlukan proses yang efisien yang mampu menghasilkan minyak DAG dengan kandungan dan kemurnian tinggi. Esterifikasi asam lemak dan gliserol menggunakan biokatalis pada sistem bebas pelarut yang disertai penghilangan air secara simultan merupakan metode yang efektif (Rosu et al., 1999; Watanabe et al., 2003; Watanabe et al., 2004).

Rosu et al. melakukan eksperimen untuk mensintesis DAG melalui esterifikasi asam lemak bebas dan gliserol pada suatu sistem bebas pelarut menggunakan Lipozyme IM yang disertai dengan pembuangan air secara simultan, mereka mendapatkan hasil 85\% yield DAG (Rosu et al., 1999). Watanabe et al. kemudian melakukan optimisasi reaksi terhadap 
sistem reaksi yang diajukan oleh Rosu et al. menggunakan Lipozyme RM IM serta mengajukan model kinetika seperti yang diperlihatkan pada Gambar 1. Model ini dikembangkan berdasarkan sistem reaksi yang dilakukan, yakni pada sistem esterifikasi antara asam lemak bebas dan gliserol pada sistem bebas pelarut yang disertai dengan pembuangan air secara simultan.

Lebih jauh lagi, Watanabe et al. kemudian melakukan eksperimen reaksi dengan sistem serupa yang dilakukan pada sistem reaktor berbeda, yakni pada reaktor packed bed kontinyu menggunakan pompa vakum. Penelitian tersebut berhasil mendapatkan kondisi optimum untuk operasi sintesis DAG pada reaktor packed bed kontinyu (Watanabe et al., 2004). Proses yang dikembangkan oleh Watanabe et al. ini telah digunakan untuk memproduksi minyak DAG dalam skala industri di Jepang saat ini.

Untuk lebih memahami perilaku reaksi pada esterifikasi asam lemak bebas dan gliserol dalam menghasilkan minyak DAG diperlukan simulasi yang dapat menggambarkan perilaku substrat. Pada studi ini, sebuah simulasi dilakukan dengan menggunakan suatu model kinetika berdasarkan mekanisme yang diusulkan. Perbedaan antara model yang diajukan dengan model yang telah ada dalam literatur terletak pada asumsi yang diambil berdasarkan jalur reaksi. Adapun perbedaan asumsi yang dimaksud antara lain pada model Watanabe et al. (2003):
(1) Laju reaksi sintesis 2-MAG dari FA dan gliserol diabaikan.

(2) Migrasi asil dari 1-MAG ke 2-MAG diabaikan

(3) Reaksi terjadi pada fasa minyak, sehingga laju pelarutan gliserol ke dalam fasa minyak diperhitungkan.

(4) Laju pembuangan air dari sistem diperhitungkan.

Sedangkan pada model yang diajukan asumsi yang digunakan adalah:

(1) Reaksi esterifikasi asam lemak dan gliserol terjadi secara bertahap.

(2) Laju reaksi mengikuti mekanisme orde 1 terhadap konsentrasi setiap substrat yang terlibat.

Simulasi ini diharapkan dapat digunakan dalam perancangan sistem untuk keperluan eksperimen di dalam laboratorium maupun dalam skala yang lebih besar.

\section{PEMODELAN \\ REAKSI \\ DIASILGLISEROL}

SINTESIS

Model yang diajukan pada penelitian ini mengikuti basis asumsi berikut.

(1) Reaksi esterifikasi asam lemak dan gliserol terjadi secara bertahap.

(2) Laju reaksi mengikuti mekanisme orde 1 terhadap konsentrasi setiap substrat yang terlibat.

(a) Enzymatic reaction

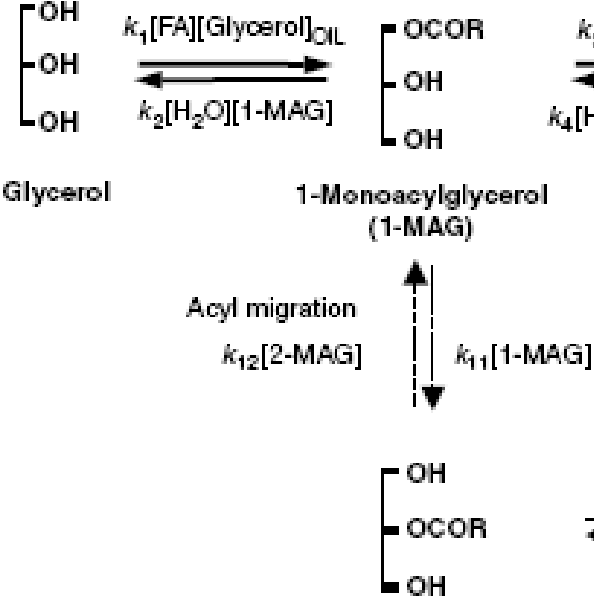

2-Monoacylglycerol (2-MAG)

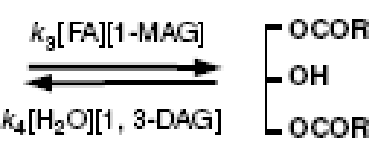

1, 3-Diacylglycerol

(1, 3-DAG)

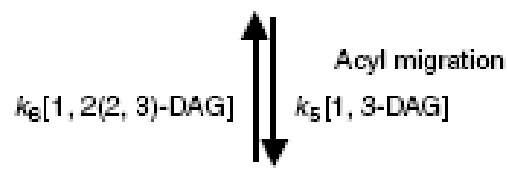

$p$
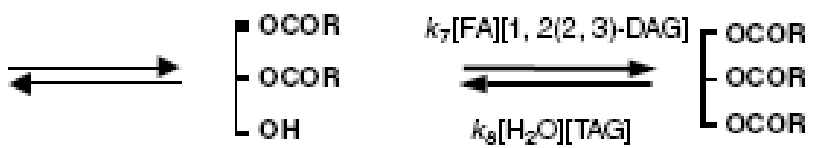

1, 2(2,3)-Diacylglycerol

$(1,2(2,3)-D A G)$

Triacylglycerol

(TAG)

(c) Dehydration

(b) Glycerol dissolution

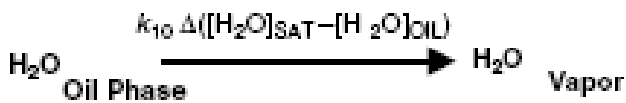


Simulasi dilakukan dengan mekanisme seperti yang terlihat pada Gambar 2. Persamaan kinetika diperoleh dengan menuliskan persamaan laju reaksi berdasarkan mekanisme dan penerapan konsep neraca massa substrat dalam sistem.

Persamaan (1)-(5) merupakan persamaan kinetika untuk model pada mekanisme yang digunakan dalam melakukan simulasi. Sedangkan persamaan (6)-(8) menunjukkan neraca massa substrat yang terdapat dalam sistem.
Terdapat 14 konstanta yang tidak diketahui pada persamaan-persamaan di atas. Keempat belas konstanta tersebut diestimasi dengan melakukan pencocokan persamaan-persamaan model dengan data yang telah disiapkan sebelumnya yang berasal dari Jurnal Watanabe et al. (2003).

Gambar 3 memperlihatkan diagram alir validasi model untuk mendapatkan keempat belas konstanta tersebut.<smiles>OCC(O)CO</smiles>

Glycerol<smiles></smiles><smiles>[R]OC(=O)OCC(CO)CO</smiles>

2-Monoacylglycerol

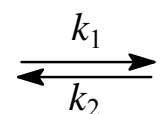<smiles>[R]OC(=O)CC(O)CO</smiles>

1-Monoacylglycerol
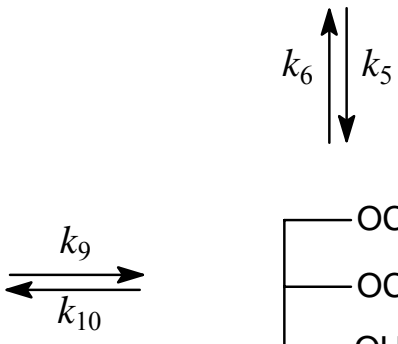

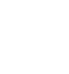

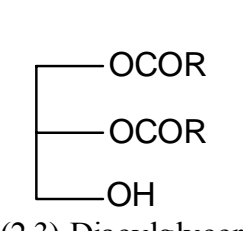

1,2(2,3)-Diacylglycerol

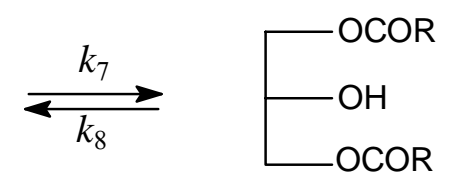

1,3-Diacylglycerol
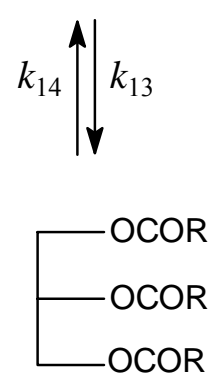

Triacylglycerol

Gambar 2. Mekanisme reaksi untuk melakukan simulasi

$$
\begin{aligned}
& \left.\frac{\mathrm{d}[1-\mathrm{MAG}]}{\mathrm{dt}}=\mathrm{k}_{1}[\mathrm{FA}][\text { glycerol }]-\mathrm{k}_{2}\left[\mathrm{H}_{2} \mathrm{O}\right][1-\mathrm{MAG}]-\left(\mathrm{k}_{5}+\mathrm{k}_{7}\right) \mathrm{FA}\right][1-\mathrm{MAG}] \\
& +\mathrm{k}_{6}\left[\mathrm{H}_{2} \mathrm{O}\right][1,2-\mathrm{DAG}]+\mathrm{k}_{8}\left[\mathrm{H}_{2} \mathrm{O}\right][1,3-\mathrm{DAG}] \\
& \frac{\mathrm{d}[2-\mathrm{MAG}]}{\mathrm{dt}}=\mathrm{k}_{3}[\mathrm{FA}][\text { glycerol }]-\mathrm{k}_{4}\left[\mathrm{H}_{2} \mathrm{O}\right][2-\mathrm{MAG}]-\mathrm{k}_{9}[\mathrm{FA}][2-\mathrm{MAG}] \\
& +\mathrm{k}_{10}\left[\mathrm{H}_{2} \mathrm{O}\right][1,2(2,3)-\mathrm{DAG}] \\
& \frac{\mathrm{d}[1,2-\mathrm{DAG}]}{\mathrm{dt}}=\mathrm{k}_{5}[\mathrm{FA}][1-\mathrm{MAG}]-\mathrm{k}_{6}\left[\mathrm{H}_{2} \mathrm{O}\right][1,2-\mathrm{DAG}]+\mathrm{k}_{9}[\mathrm{FA}][2-\mathrm{MAG}] \\
& -\mathrm{k}_{10}\left[\mathrm{H}_{2} \mathrm{O}\right][1,2(2,3)-\mathrm{DAG}] \\
& \frac{\mathrm{d}[1,3-\mathrm{DAG}]}{\mathrm{dt}}=\mathrm{k}_{7}[\mathrm{FA}][1-\mathrm{MAG}]-\mathrm{k}_{8}\left[\mathrm{H}_{2} \mathrm{O}\right][1,3-\mathrm{DAG}]-\mathrm{k}_{13}[\mathrm{FA}][1,3-\mathrm{DAG}] \\
& +\mathrm{k}_{14}\left[\mathrm{H}_{2} \mathrm{O}\right][\mathrm{TAG}] \\
& \frac{\mathrm{d}[\mathrm{TAG}]}{\mathrm{dt}}=\mathrm{k}_{11}[\mathrm{FA}][1,2(2,3)-\mathrm{DAG}]-\mathrm{k}_{12}\left[\mathrm{H}_{2} \mathrm{O}\right][\mathrm{TAG}]+\mathrm{k}_{13}[\mathrm{FA}][1,3-\mathrm{DAG}] \\
& -\mathrm{k}_{14}\left[\mathrm{H}_{2} \mathrm{O}\right][\mathrm{TAG}] \\
& {[\mathrm{FA}]_{\mathrm{t}}=[\mathrm{FA}]_{0}-[1-\mathrm{MAG}]_{\mathrm{t}}-[2-\mathrm{MAG}]_{\mathrm{t}}-2[1,2-\mathrm{DAG}]_{\mathrm{t}}-2[1,3-\mathrm{DAG}]_{\mathrm{t}}-3[\mathrm{TAG}]} \\
& {[\text { glycerol }]_{\mathrm{t}}=[\text { glycerol }]_{0}-[1-\mathrm{MAG}]-[2-\mathrm{MAG}]-[1,2-\mathrm{DAG}]-[1,3-\mathrm{DAG}]-[\mathrm{TAG}]} \\
& {\left[\mathrm{H}_{2} \mathrm{O}\right]_{\mathrm{t}}=[1-\mathrm{MAG}]_{\mathrm{t}}+[2-\mathrm{MAG}]_{\mathrm{t}}+2[1,2-\mathrm{DAG}]_{\mathrm{tt}}+2[1,3-\mathrm{DAG}]+3[\mathrm{TAG}]_{\mathrm{t}}}
\end{aligned}
$$




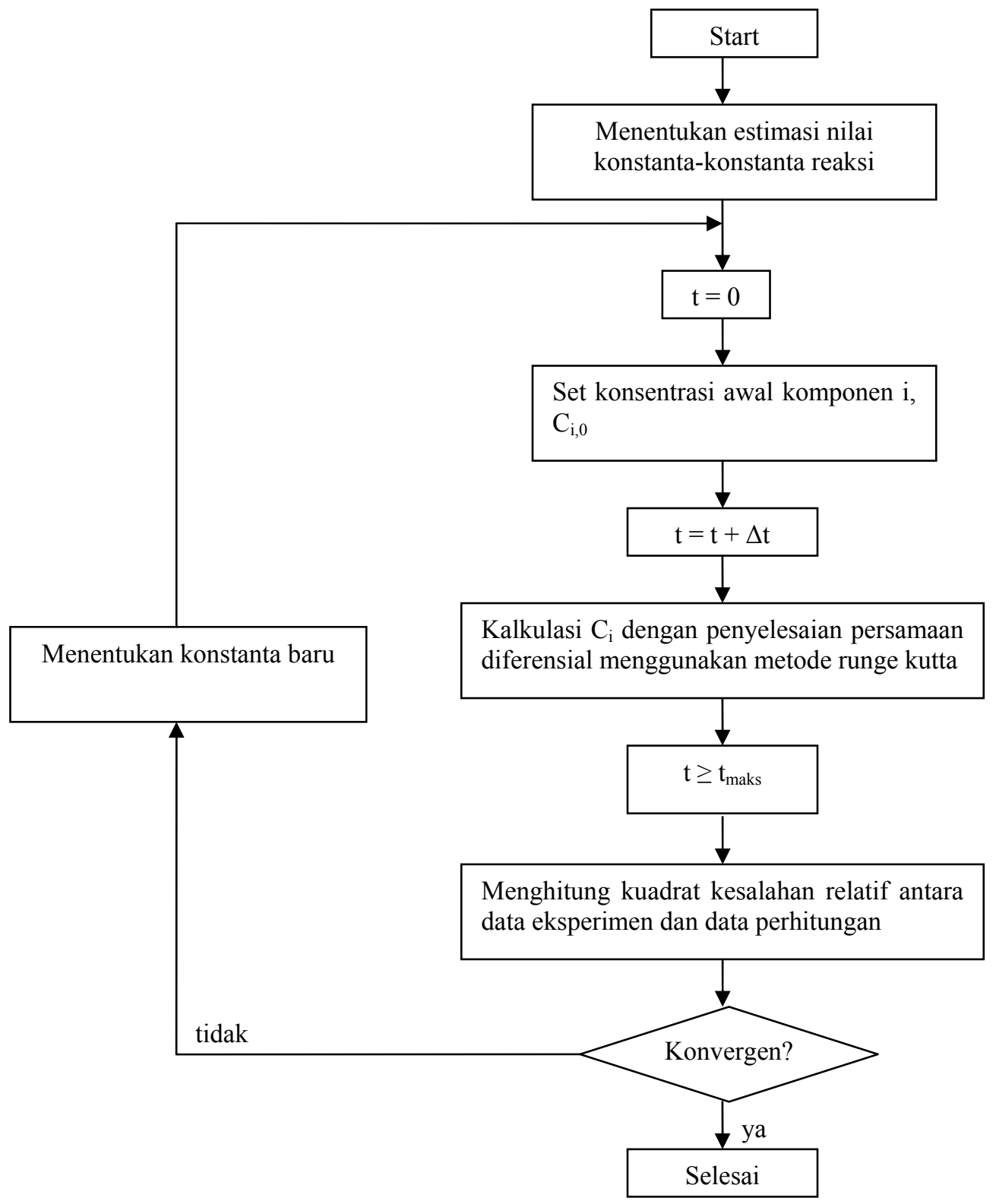

Gambar 3. Diagram alir validasi model

Dengan mengasumsikan nilai konstanta $k_{1}-k_{14}$, persamaan (8)-(15) diselesaikan secara numerik menggunakan metode Runge-Kutta. Selisih waktu yang digunakan pada perhitungan ditetapkan sebesar 0,1 jam. Hasil pencocokan terbaik diperoleh dengan meminimalkan jumlah kuadrat kesalahan relatif antara perhitungan menggunakan model dan data eksperimen untuk konsentrasi asam lemak, 1-MAG, 2-MAG, 1,2DAG, 1,3-DAG dan TAG. Data eksperimen berasal dari reaksi esterifikasi dilakukan pada $50^{\circ} \mathrm{C}$ dengan rasio molar asam lemak dan gliserol 2,0, konsentrasi resin enzim terimobilisasi 5\% (basis kering), dan resident time 60 detik. Penghilangan air dilakukan dengan kondisi vakum pada $3 \mathrm{mmHg}(0,4 \mathrm{kPa})$ yang dilaporkan Watanabe et al. (2003).

\section{HASIL DAN PEMBAHASAN} Nilai Estimasi Konstanta Kinetika

Nilai estimasi konstanta kinetika pada model yang akan disimulasikan disajikan pada Tabel 1. Nilai konstanta kinetika yang diperoleh pada model ini, pada beberapa reaksi berbeda dengan nilai yang terdapat dalam literatur untuk reaksi yang ekivalen pada model sebelumnya (Watanabe et al., 2003).

Sebagai contoh, konstanta kinetika untuk sintesis 1,3-DAG dari 1-MAG dalam model ini bernilai $2,85 \times 10^{-4}$, nilai ini hampir sama denga nilai yang diperoleh dari literatur yaitu $2,91 \times 10^{-4}$ (Watanabe et al., 2003). Sedangkan nilai konstanta $k_{3}$, $k_{5}, k_{13}$ baru pertama kali diajukan sehingga tidak ada perbandingan dengan literatur. 
Tabel 1. Nilai estimasi konstanta kinetika dari model yang diusulkan (dalam $\mathrm{L} \mathrm{mol}^{-1} \mathrm{~s}^{-1}$ )

\begin{tabular}{crcr}
\hline Konstanta & Nilai Estimasi & Konstanta & Nilai Estimasi \\
\hline$k_{1}$ & $2,30 \times 10^{-04}$ & $k_{2}$ & $1,39 \times 10^{-07}$ \\
$k_{3}$ & $1,42 \times 10^{-06}$ & $k_{4}$ & $6,94 \times 10^{-08}$ \\
$k_{5}$ & $4,17 \times 10^{-07}$ & $k_{6}$ & $2,56 \times 10^{-08}$ \\
$k_{7}$ & $2,85 \times 10^{-04}$ & $k_{8}$ & $1,41 \times 10^{-06}$ \\
$k_{9}$ & $2,63 \times 10^{-04}$ & $k_{10}$ & $2,78 \times 10^{-07}$ \\
$k_{11}$ & $1,39 \times 10^{-06}$ & $k_{12}$ & $1,39 \times 10^{-06}$ \\
$k_{13}$ & $3,48 \times 10^{-06}$ & $k_{14}$ & $4,17 \times 10^{-08}$ \\
\hline
\end{tabular}

Tabel 2. Perbandingan konstanta kinetika untuk reaksi yang ekivalen antara hasil perhitungan dengan hasil literatur (Watanabe et al., 2003).

\begin{tabular}{cccc}
\hline \multicolumn{2}{c}{ Hasil Perhitungan } & \multicolumn{2}{c}{ Hasil Literatur } \\
\hline Konstanta Kinetika & Nilai $\left(\mathrm{L} \mathrm{mol}^{-1} \mathrm{~s}^{-1}\right)$ & Konstanta Kinetika & Nilai $\left(\mathrm{L} \mathrm{mol}^{-1} \mathrm{~s}^{-1}\right)$ \\
\hline $\mathrm{k}_{1}$ & $2,30 \times 10^{-04}$ & $\mathrm{k}_{1}$ & $7,4 \times 10^{-4}$ \\
$\mathrm{k}_{2}$ & $1,39 \times 10^{-07}$ & $\mathrm{k}_{2}$ & $4,01 \times 10^{-04}$ \\
$\mathrm{k}_{7}$ & $2,85 \times 10^{-04}$ & $\mathrm{k}_{3}$ & $2,91 \times 10^{-4}$ \\
$\mathrm{k}_{8}$ & $1,41 \times 10^{-06}$ & $\mathrm{k}_{4}$ & $7,10 \times 10^{-04}$ \\
$\mathrm{k}_{11}$ & $1,39 \times 10^{-06}$ & $\mathrm{k}_{7}$ & $1,84 \times 10^{-3}$ \\
$\mathrm{k}_{12}$ & $1,39 \times 10^{-06}$ & $\mathrm{k}_{8}$ & $2,86 \times 10^{-03}$ \\
\hline
\end{tabular}

Tabel 3. Hasil analisis sensitivitas konstanta kinetika dari model yang diajukan

\begin{tabular}{|c|c|c|c|c|c|c|c|}
\hline Konstanta & Nilai & SSE & Deviasi & Konstanta & Nilai & SSE & Deviasi \\
\hline \multirow{3}{*}{$k_{1}$} & $1,15 \times 10^{-04}$ & 1,81 & $40,39 \%$ & \multirow{3}{*}{$k_{8}$} & $7,05 \times 10^{-07}$ & 1,29 & $24,15 \%$ \\
\hline & $2,30 \times 10^{-04}$ & 1,29 & Minimum & & $1,41 \times 10^{-06}$ & 1,29 & Minimum \\
\hline & $4,59 \times 10^{-04}$ & 2,07 & $60,49,01 \%$ & & $2,82 \times 10^{-06}$ & 1,29 & $22,77 \%$ \\
\hline \multirow{3}{*}{$k_{2}$} & $6,94 \times 10-^{08}$ & 1,29 & $2,27 \%$ & \multirow{3}{*}{$k_{9}$} & $1,32 \times 10^{-04}$ & 1,30 & $61,02 \%$ \\
\hline & $1,39 \times 10^{-07}$ & 1,29 & Minimum & & $2,63 \times 10^{-04}$ & 1,29 & Minimum \\
\hline & $2,78 \times 10^{-07}$ & 1,29 & $4,55 \%$ & & $5,26 \times 10^{-04}$ & 1,30 & $68,54 \%$ \\
\hline \multirow{3}{*}{$k_{3}$} & $7,12 \times 10^{-07}$ & 1,30 & $8,74 \%$ & \multirow{3}{*}{$k_{10}$} & $1,39 \times 10^{-07}$ & 1,29 & $0,02 \%$ \\
\hline & $1,42 \times 10^{-06}$ & 1,29 & Minimum & & $2,78 \times 10^{-07}$ & 1,29 & Minimum \\
\hline & $2,85 \times 10^{-06}$ & 1,31 & $13,79 \%$ & & $5,56 \times 10^{-07}$ & 1,29 & $0,05 \%$ \\
\hline \multirow{3}{*}{$k_{4}$} & $3,47 \times 10^{-08}$ & 1,29 & $0,01 \%$ & \multirow{3}{*}{$k_{11}$} & $1,18 \times 10^{-04}$ & 1,30 & $71,46 \%$ \\
\hline & $6,94 \times 10^{-08}$ & 1,29 & Minimum & & $2,36 \times 10^{-04}$ & 1,29 & Minimum \\
\hline & $1,39 \times 10^{-07}$ & 1,29 & $0,01 \%$ & & $4,72 \times 10^{-04}$ & 1,30 & $86,98 \%$ \\
\hline \multirow{3}{*}{$k_{5}$} & $2,08 \times 10^{-07}$ & 1,29 & $11,78 \%$ & \multirow{3}{*}{$k_{12}$} & $6,94 \times 10^{-07}$ & 1,29 & $0,55 \%$ \\
\hline & $4,17 \times 10^{-07}$ & 1,29 & Minimum & & $1,39 \times 10^{-06}$ & 1,29 & Minimum \\
\hline & $8,33 \times 10^{-07}$ & 1,29 & $23,73 \%$ & & $2,78 \times 10^{-06}$ & 1,29 & $1,11 \%$ \\
\hline \multirow{3}{*}{$k_{6}$} & $1,28 \times 10^{-08}$ & 1,29 & $0,01 \%$ & \multirow{3}{*}{$k_{13}$} & $1,74 \times 10^{-06}$ & 1,30 & $8,49 \%$ \\
\hline & $2,56 \times 10^{-08}$ & 1,29 & Minimum & & $3,48 \times 10^{-06}$ & 1,29 & Minimum \\
\hline & $5,12 \times 10^{-08}$ & 1,29 & $0,01 \%$ & & $6,96 \times 10^{-06}$ & 1,31 & $19,01 \%$ \\
\hline \multirow{3}{*}{$k_{7}$} & $1,42 \times 10^{-04}$ & 1,90 & $47,22 \%$ & \multirow{3}{*}{$k_{14}$} & $2,08 \times 10^{-08}$ & 1,29 & $0,04 \%$ \\
\hline & $2,85 \times 10^{-04}$ & 1,29 & Minimum & & $4,17 \times 10^{-08}$ & 1,29 & Minimum \\
\hline & $5,69 \times 10^{-04}$ & 1,60 & $24,29 \%$ & & $8,33 \times 10^{-08}$ & 1,29 & $0,08 \%$ \\
\hline
\end{tabular}

Tabel 2 memperlihatkan perbandingan antara nilai konstanta kinetika yang diperoleh dari hasil perhitungan dengan yang terdapat di dalam literatur (Watanabe et al., 2003).

Untuk menguji kesensitivan konstanta kinetika yang diperoleh dilakukan analisis sensitivitas dengan cara menambahkan nilai suatu konstanta $-50 \%$ dan $+50 \%$ sementara nilai konstanta lainnya dibiarkan tetap, kemudian dilihat kesalahan yang dihasilkan sebagai akibat dari perubahan itu. Tabel 3 memperlihatkan hasil analisis sensitivitas konstanta kinetika yang diperoleh dari model yang diusulkan.

Pada Tabel 3 terlihat bahwa parameter kinetika yang sensitif adalah $k_{1}, k_{3}, k_{7}, k_{9}, k_{11}$ dan $k_{13}$. Hasil ini cukup wajar mengingat $k_{1}$ dan $k_{7}$ berturut-turut merupakan konstanta untuk pembentukan 1-MAG dari asam lemak dan gliserol serta konstanta untuk pembentukan 1,3-DAG dari asam lemak dan 1-MAG. 
Karena kedua senyawa tersebut merupakan komponen utama yang dihasilkan dalam reaksi yang dilakukan maka laju sintesis kedua senyawa tersebut memiliki efek yang signifikan.

Beberapa parameter tidak memiliki sensitivitas yang cukup baik terutama untuk laju reaksi hidrolisis. Karena pada eksperimen yang dilakukan Watanabe dilakukan pembuangan air secara simultan yang memiliki efek sangat signifikan, maka sensitivitas parameter kinetika untuk hidrolisis menjadi rendah. Hal ini dapat terjadi karena laju penghilangan air dari dalam sistem lebih dominan dibandingkan laju reaksi hidrolisis air dengan produk asilgliserol.

\section{Simulasi}

Simulasi dilakukan dengan mengubah rasio konsentrasi awal asam lemak bebas dan gliserol. Profil konsentrasi substrat (reaktan dan produk) terhadap waktu reaksi, yield maksimum DAG, konversi asam lemak, dan konversi gliserol diamati. Gambar 4 memperlihatkan hasil simulasi dengan rasio konsentrasi awal asam lemak dan gliserol yang bervariasi.

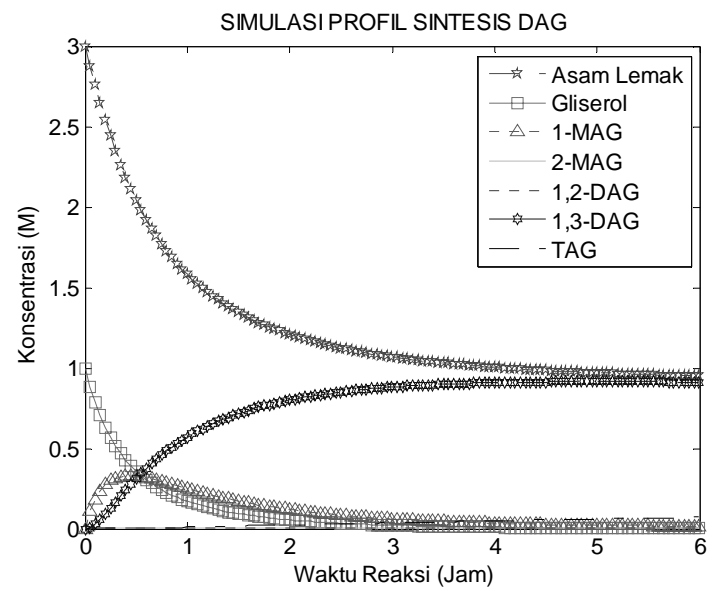

(a)

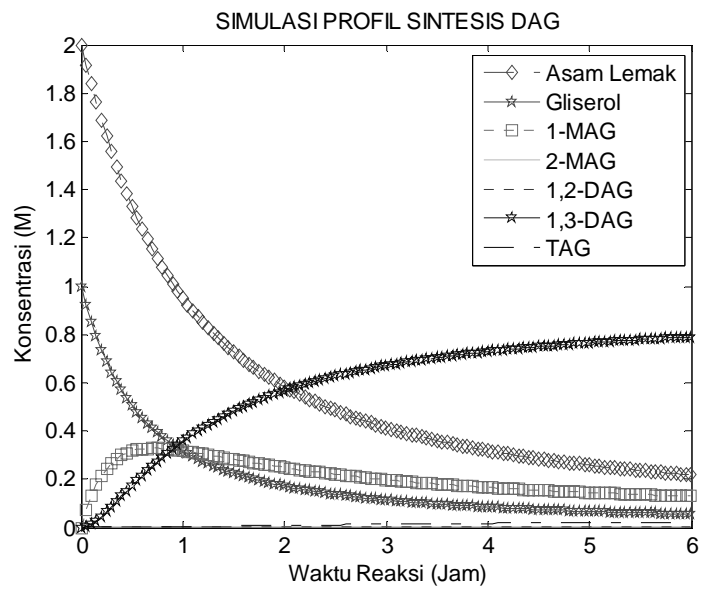

(b)

Gambar 4. Profil konsentrasi substrat hasil simulasi menggunakan model dengan rasio asam lemak bebas : gliserol sebesar (a) $3: 1$ dan (b) 2:1
Pada kedua hasil simulasi yang dilakukan untuk rentang waktu 6 jam terlihat bahwa peningkatan konsentrasi 1-MAG dan 1,3-DAG sangat tajam, jauh lebih besar dari 2-MAG, 1,2-DAG, dan TAG. Hal ini berkaitan dengan kespesifikan enzim yang digunakan pada eksperimen Watanabe pada sn-1,3 sehingga pembentukan ikatan ester pada sn-2 tidak dikatalisasi. Akibatnya sintesis ketiga substrat yang memiliki ikatan ester pada sn-2 menjadi sangat kecil.

Meskipun reaksi esterifikasi merupakan reaksi yang bersifat reversible, namun karena pada eksperimen Watanabe disertakan penghilangan air secara simultan, maka kesetimbangan tidak terjadi, dan pembentukan produk (DAG) terus berlanjut hingga reaktan habis terkonversi, seperti tampak pada Gambar 4a.

Pada gambar 4b, peningkatan konsentrasi DAG tidak setajam pada gambar 4a. Banyaknya asam lemak bebas yang berada dalam sistem mendorong 1MAG untuk segera bereaksi membentuk 1,3-DAG sehingga pada rasio konsentrasi awal asam lemak bebas dan gliserol 3:1 pembentukan 1,3-DAG menjadi lebih cepat.

Pada awal reaksi, 1-MAG dengan cepat terbentuk, namun segera terkonsumsi menjadi 1,3DAG. Tajamnya peningkatan konsentrasi 1-MAG di awal reaksi disebabkan karena masih banyak gliserol yang merupakan reaktan pembentuk 1-MAG. Ketika gliserol telah habis, maka 1-MAG menurun dengan drastis akibat pembentukan 1,3-DAG. Hal ini ditandai dengan menurunnya konsentrasi 1-MAG setelah mencapai konsentrasi maksimum.

Gambar 5 memperlihatkan pengaruh rasio konsentrasi awal reaktan terhadap konversinya. Pada Gambar 5a, konversi asam lemak terjadi pada saat rasio konsentrasi awal asam lemak bebas dan gliserol $3: 2$, namun dari Gambar 5b, terlihat bahwa konversi gliserol cukup rendah pada rasio tersebut. Sebaliknya pada rasio asam lemak bebas dan gliserol 3:1, konversi gliserol sangat tinggi namun konversi asam lemak bebas sangat rendah.

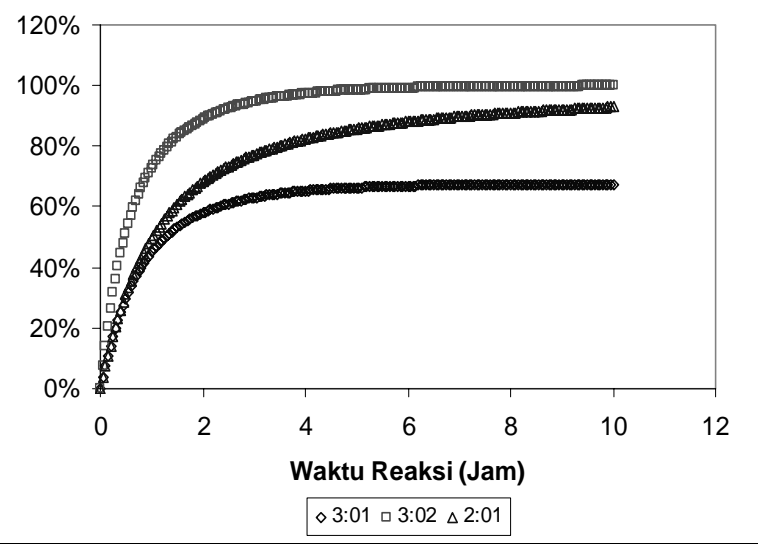

(a) 


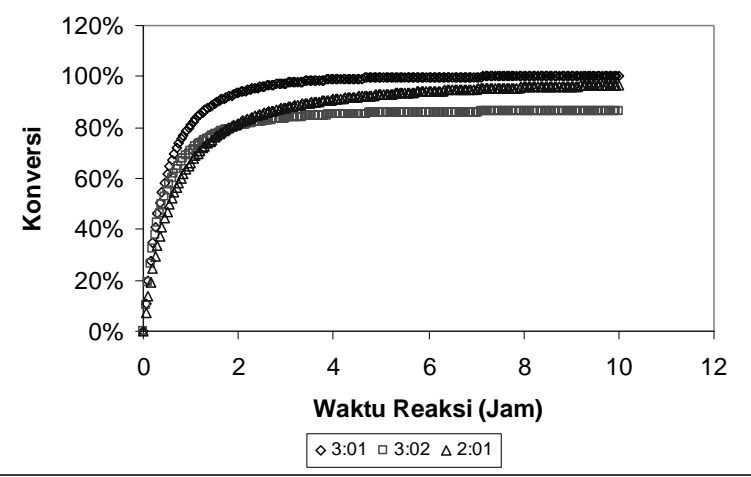

(b)

Gambar 5. Pengaruh rasio reaktan terhadap konversi (a) asam lemak dan (b) gliserol

Konversi asam lemak dan gliserol mencapai hasil yang cukup memuaskan ketika rasio asam lemak bebas terhadap gliserol $2: 1$, pada rasio ini jumlah stoikiometris kedua substrat sesuai dengan pembentukan ikatan ester pada gliserol yang terjadi pada sintesis DAG.

Selain profil konsentrasi substrat, yield maksimum DAG dari berbagai rasio tersebut juga diamati seperti terlihat pada Gambar 6. Terlihat pada gambar tersebut bahwa yield maksimum DAG tercapai ketika rasio asam lemak berbas terhadap gliserol mencapai 2:1. Dengan demikian, dapat disimpulkan bahwa rasio konsentrasi awal asam lemak bebas terhadap gliserol sebesar 2:1 merupakan rasio optimum pada esterifikasi asam lemak bebas dengan gliserol untuk menghasilkan minyak DAG.

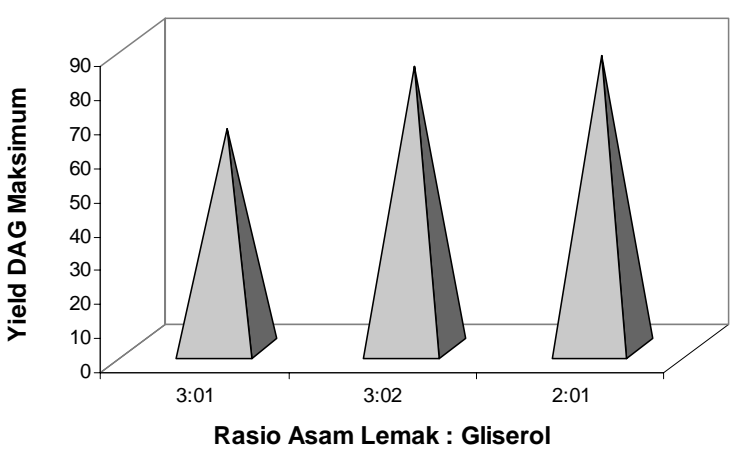

Gambar 6. Pengaruh rasio reaktan terhadap yield maksimum DAG

\section{KESIMPULAN DAN SARAN}

Simulasi esterifikasi asam lemak bebas dan gliserol untuk menghasilkan 1,3-DAG telah dilakukan dalam rangka mempelajari perilaku substrat yang terdapat dalam sistem. Rasio konsentrasi awal asam lemak dan gliserol yang digunakan sangat mempengaruhi efisiensi proses karena berkaitan langsung dengan konversi reaktan.

Pada studi yang dilakukan saat ini terdapat kendala berupa sulitnya memperoleh data yang akan digunakan untuk melakukan validasi. Sebagai akibatnya, kondisi yang dapat divariasikan pada simulasi hanya rasio reaktan. Pada penelitian selanjutnya disarankan untuk melakukan validasi menggunakan beberapa set data sehingga mekanisme yang diusulkan ini dapat digunakan dalam kondisi yang lebih luas lagi.

\section{DAFTAR PUSTAKA}

Berger, M., Laumen, K., and Schneider, M. (1992), Enzymatic esterification of glycerol. I. Lipasecatalyzed synthesis of resioisomerically pure 1,3-snDAGs, J. Am. Oil Chem. Soc., 69, pp. 955-960.

Flickinger, B.D. and Matsuo, N., (2003), Nutritional Characteristic of DAG Oil, Lipids, 38, pp. 129-132

Katsuragi Y. and Yasukawa, T., (2004), Diacylglycerols, Diacylglycerol Oil 1, pp. 1-15.

Kondo, H., Hase, T., Murase, T., and Tokimitsu, I., (2003), Digestion and assimilation features of dietary DAG in the rat small intestine, Lipids 38, pp. 25-30.

Maki, K.C., Davidson, M.H., Tsushima, R., Matsuo, N., Tokimitsu, I., Umporowicz, D.M., Dicklin, M.R., Foster, G.S., Ingram, K.A., Anderson, B.D. Frost, S.D., and Bell, M., (2002), Consumption of diacylglycerol oil as part of a mildly reduced-energy diet enhances loss of body weight and fat compared with a triacylglycerol control oil, Am. J. Clin. Nutr., 76, pp. 1230-1236.

Nagao, T., Watanabe, H., Goto, N., Onizawa, K., Taguchi, H., Matsuo, N., Yasukawa, T., Tsushima, R., Shimasaki, H., and Itakura, H., (2000), Dietary diacylglycerol suppresses accumulation of body fat compared to triacylglycerol in men in a double-blind controlled trial, J. Nutr., 130, pp. 792-797.

Plou, J.F., Barandiarn, M., Calvo, V.M., Ballesteros, A., and Paster, E., (1996), High-yield production of mono- and di-oleylglycerol by lipase-catalyzed hydrolysis of triolein, Enzyme Microb. Technol., 18, pp. 66-71.

Rosu, R., Yasui, M., Iwasaki, Y., and Yamane, T., (1999), Enzymatic synthesis of symmetrical 1,3DAGs by direct esterification of glycerol in solventfree system, J. Am. Oil Chem. Soc., 76, pp. 839-843.

Sontang, N.O.V., (1982), Glycerolysis of fats and methyl esters-status, J. Am. Oil Chem. Soc., 59, pp. 795A-802A.

Tada, N., Watanabe, H., Matsuo, N., Tokimitsu, I., and Okazaki, M., (2001), Dynamics of postprandial remnant-like lipoprotein particles in serum after loading of diacylglycerols, Clin. Chim. Acta, 311, pp. $109-117$.

Watanabe, H., Onizawa, K., Taguchi, H., Kobori, M., Chiba, H., Naito, Y., Matsuo, N., Yasukawa, T., 
Hattori, M., and Shimasaki, H., (1997), Nutritional characterization of diacylglycerols in rats, J. Jpn. Oil Chem. Soc., 46, pp. 301-307.

Watanabe, T., Shimizu, M., Sugiura, M., Sato, M., Kohori, J., Yamada, N., and Nakanishi, K., (2003), Optimization of reaction conditions for production of DAG using immobilized 1,3-regiospecific lipase Lipozyme RM IM, J. Am. Oil Chem. Soc., 80, pp. 1201-1207.
Watanabe, T., Sugiura, M., Sato, M., Yamada, N., and Nakanishi, K., (2004), Diacylglycerol Production in a Packed Bed Bioreactor, Process Biochemistry 40, pp. 637-643.

Yamane, T., Kang, S.T., Kawahara, K., and Koizumi, Y., (1994), High-yield DAG formation by solid-phase enzymatic glycerolysis of hydrogenenated beef tallow, J. Am. Oil Chem. Soc., 71, pp. 339-342. 